\title{
Modelling and mapping critical loads and exceedances for the Georgia Basin, British Columbia, using a zero base-cation depletion criterion
}

\author{
Mina NASR, Mark CASTONGUAY, Jae OGILVIE, Beverley A. RAYMOND ${ }^{\dagger 1)}$ and Paul A. ARP* \\ Faculty of Forestry and Environmental Management, 28 Dineen Drive, University of New Brunswick, Fredericton, NB E3B 6C2, \\ Canada \\ ${ }^{1)}$ Environment Canada, 201-401 Burrard Street, Vancouver, BC V6C 3S5, Canada \\ ${ }^{\dagger}$ Deceased \\ *e-mail corresponding author: arp1@unb.ca
}

\begin{abstract}
Critical load (CL) and exceedance maps of sulphur (S) and nitrogen (N) for upland soils were generated for the Georgia Basin, British Columbia, Canada, by synthesizing available data layers for atmospheric deposition, climate (precipitation, temperature), soil, site classification and elevation. Critical loads were determined using the steady-state mass-balance model and a criterion based on zero-tolerance for further base-cation depletion. The resulting CL values were generally lowest on ridge tops and increased towards valleys. Critical load exceedance ranged from 13\% of the Georgia Basin under wet deposition to 32\% under modelled total (wet and dry) deposition. Moreover, exceedance increased by an additional 10\% when considering upland areas only for the Georgia Basin. Significant portions of the Georgia Basin are predicted to experience exceedance-enhanced base-cation depletion rates above $200 \mathrm{eq} \mathrm{ha} \mathrm{y}^{-1} \mathrm{y}^{-1}$ and turn-over times to a final new base saturation state within 200 years under continued atmospheric $S$ and $N$ deposition.
\end{abstract}

Key words: critical loads, exceedances, soil acidification, base-cation depletion, sulphur, nitrogen

\section{INTRODUCTION}

Southwest British Columbia, Canada, is a region experiencing significant growth in both human population and shipping traffic to the port of Vancouver, with consequent increases in transportation-related emissions of acid deposition precursors, i.e., nitrogen oxides and sulphur dioxide. Coastal British Columbia has also been recognized as an area of high sensitivity to acidic deposition (Wiens 1987; Environment Canada 2004) due to resistant bedrock geology and poor soil buffering capacity. The risk of harmful effects on natural ecosystems increases when incoming pollutants exceed the critical load (CL) of ecosystems, such as aciddeposition induced soil acidification and base-cation depletion (Nilsson \& Grennfelt 1988; Posch et al. 2005). Soil acidification and subsequent base-cation depletion in upland (forest) soils in relation to acid precipitation and other factors such as forest harvesting have been reviewed by Watmough \& Dillon (2001, 2006), Huntington (2005), Duchesne \& Houle (2006), Houle et al. (2006) and Kreutzweiser et al. (2008) for the North American context. Changes in soil base-cation content, however, are not easily relatable to external stressors. In part, this is due to considerable site-to-site variations in soils, forests, and forest management practices, and also due to a general lack of long-term records. Nevertheless, there is a consensus that upland soils likely experience base-cation losses when subject to atmospheric acid deposition and forest logging.
Furthermore, such changes may affect forest health and tree productivity (Fenn et al. 2006).

The objective of this study was to determine and map CL, exceedance and base-cation depletion for areas potentially subject to atmospherically induced basecation depletion within the Georgia Basin of southwest British Columbia. The deposition of atmospheric acidity, originating from industrial and urban sulphur (S) and nitrogen $(\mathrm{N})$ emissions, is thought to accelerate soil leaching and base-cation depletion, especially due to the high precipitation rates in the region. Upland areas with shallow soils across the generally mountainous and valley-incised terrain down-wind from urban and industrial centres are of particular concern. The approach presented in this paper deals with quantifying gradual base-cation losses from soils over time using a steady-state mass balance (SSMB) approach (Posch et al. 1995; Ouimet et al. 2001). The objective was to place $\mathrm{CL}$ and exceedance calculations into the direct context of sustainable forest and soil management policies and practices (Moayeri et al. 2001) by introducing 'no further change in soil base saturation' as the main CL criterion for soil acidification. While soil base saturation, by itself, is a poor indicator of soil acidity according to Skyllberg et al. (2001) and Johnson (2002), it provides a means to track gains and losses in soil base cations through space and time in response to external inputs and stressors, be they related to atmospheric deposition, soil weathering, and land-use practices. 


\section{METHODS}

\subsection{Model formulation}

For simplicity, the model formulation in the current study focused on potential base-cation depletion rates only, without considering dynamic input-output complications. Episodic factors referring to forest fires, harvesting, insect infestations and other dynamic disturbance processes that affect forest growth and mortality were not addressed, and secondary processes referring to nutrient cycling were also not considered. Only atmospheric deposition and soil weathering were considered as the primary acid-[sulphate $\left(\mathrm{SO}_{4}{ }^{2-}\right)$, nitrate $\left(\mathrm{NO}_{3}^{-}\right)$, ammonium $\left.\left(\mathrm{NH}_{4}^{+}\right)\right]$and base-[calcium $\left(\mathrm{Ca}^{2+}\right)$, magnesium $\left(\mathrm{Mg}^{2+}\right)$ and potassium $\left.\left(\mathrm{K}^{+}\right)\right]$cation inputs to derive $C L$, exceedance and base-cation depletion. These inputs were kept constant across time. Critical load and exceedance were determined using the SSMB model and a zero base-cation depletion criterion:

$$
\begin{gathered}
C L=N_{u p}+N_{i m m}-N_{f i x}+B C_{d e p}+ \\
\quad+B C_{w}-B C_{u p}+A C_{\text {leach }, C L} \\
\text { Exceedance }=S_{\text {dep }}+N_{\text {dep }}-C L
\end{gathered}
$$

where $B C$ denotes base cations $\left(\mathrm{Ca}^{2+}, \mathrm{Mg}^{2+}, \mathrm{K}^{+}\right), A C$ denotes acid cations $\left(\mathrm{H}^{+}\right.$ions and hydrolysing cations notably aluminium $\left(\mathrm{Al}^{3+}\right)$ ), the subscripts $d e p$, fix, imm, $u p$, and $w$ refer to total atmospheric deposition (wet and dry), fixation, immobilization, net vegetation uptake and soil weathering, respectively. Furthermore, $A C_{\text {leach, } C L}$ refers to the rate of soil acid-cation leaching once the critical zero base-cation depletion load is achieved. This quantity is equivalent to critical acid-neutralizingcapacity (ANC) leaching in conventional SSMB terminology (Ouimet et al. 2006), such that $A C_{\text {leach, } C L}=$ $-A N C_{\text {leach. }}$. All terms are in units of eq $\mathrm{ha}^{-1} \mathrm{y}^{-1}$. Potential net soil acidification impacts due to combined sodium $\left(\mathrm{Na}^{+}\right)$and chloride $\left(\mathrm{Cl}^{-}\right)$deposition were assumed to be negligible.

The soil base-cation weathering rate $\left(B C_{w}\right)$ as estimated below, accounts for variations in soil rooting depth $[D(\mathrm{~m})]$, soil bulk density $\left[\rho_{b}\left(\mathrm{~g} \mathrm{~cm}^{-3}\right)\right]$, soil temperature, organic matter content $[O M(\%)]$ and coarse fragment content $[C F(\%)]$, as follows:

$$
B C_{w}=\frac{\rho_{b}}{\rho_{\mathrm{H}_{2} \mathrm{O}}} D\left(1-\frac{C F}{100}\right)\left(1-\frac{O M}{100}\right) B C_{w, 0} \exp \left(A \frac{T-T_{\text {ref }}}{T T_{\text {ref }}}\right)
$$

where $T$ is temperature, $T_{r e f}$ is the reference temperature $\left(2.6{ }^{\circ} \mathrm{C}\right), A$ is a temperature coefficient for soil weathering (3600), $\rho_{H 2 O}$ is the bulk density of water $(1 \mathrm{~g}$ $\left.\mathrm{cm}^{-3}\right)$. Furthermore, $B C_{w, 0}$ is the base-cation weathering rate (eq ha $\left.{ }^{-1} \mathrm{y}^{-1} \mathrm{~m}^{-1}\right)$ of mineral soil for which $\rho_{b}$ is $1 \mathrm{~g}$ $\mathrm{cm}^{-3}, O M=0 \%$ and $C F=0 \%$. This base rate was estimated from (de Vries 1991):

- if substrate $=0$ then $B C_{w, 0}=0$;

- if substrate $=1$ then $B C_{w, 0}=56.7 \times$ clay $-0.32 \times$ clay $^{2}$;
- if substrate $=2$ then $B C_{w, 0}=500+53.6 \times$ clay -0.18 $\times$ clay $^{2}$

- if substrate $=3$ then $B C_{w, 0}=500+59.2 \times$ clay;

- if substrate $=4$ then $B C_{w, 0}=1500+59.2 \times$ clay;

where clay refers to the clay fraction of the mineral soil (based on soil particle analysis), and substrate refers to weathering class as follows: 0 for organic matter, 1, 2, 3 and 4 for soil minerals derived from, e.g., granites, rhyolite, quartzite, gneiss and sandstones (1), siltstone, mudstone, conglomerates, diorites and other rock types with mixed silicaceous minerals (2), mafic rock types (3), and calcareous substrates (4).

The leaching rates of base and acid cations from soils were estimated by considering the acid-base cation loads and the resulting cation-exchange processes within the soil. This exchange follows the laws of mass action and charge conservation. Cation exchange processes in acidic soils, typically dominated by $\mathrm{Ca}^{2+}$ (or $\left.\mathrm{Ca}^{2+}+\mathrm{Mg}^{2+}\right), \mathrm{Al}^{3+}$ and $\mathrm{H}^{+}$ions, are generally represented by Gapon and Gaines-Thomas formulations (Matschonat \& Vogt 1998), but cation leachate from soils tends to be linearly equivalent to incoming atmospheric S and $\mathrm{N}$ deposition loads (Dise et al. 2001). Translating this into a simple expression for cation exchange between the soil solution and exchange sites under steady-state leads to:

$$
K_{\text {exch }}=\frac{C E C-B S+\Delta x}{B S-\Delta x} \frac{B C_{\text {leach }}+\Delta x}{A C_{\text {leach }}-\Delta x}
$$

where $K_{\text {exch }}$ is the cation exchange constant, $C E C$ and $B S$ refer to the cation exchange capacity and the sum of exchangeable base cations $\left(\mathrm{Ca}^{2+}, \mathrm{Mg}^{2+}\right.$ and $\left.\mathrm{K}^{+}\right)$in the rooted portion of the soil, $B C_{\text {leach }}=B C_{\text {dep }}+B C_{w}-B C_{u p}$ is the base cation leaching rate at steady-state, $A C_{\text {leach }}=$ $S_{\text {dep }}+N_{\text {dep }}-N_{u p}-N_{\text {imm }}+N_{\text {fix }}-B C_{\text {leach }}$ is the acid cation leaching rate at steady-state, and $\Delta x$ is the annual extent of acid-base cation exchange needed to gradually adjust $B S$ towards the final $B S$ value (denoted as $B S_{f}$ ) at steadystate.

Setting current levels of base saturation in \% (denoted as $B S_{C L}$ ) as the reference criterion for zero base-cation depletion, it follows from Eqn 1 and Eqn 4 with $\Delta x=0$ that:

$$
A C_{\text {leach, }, C L}=\frac{1}{K_{\text {exch }}} \frac{C E C-B S_{C L}}{B S_{C L}} B C_{\text {leach }}
$$

and

$$
B S_{f}=\frac{100}{1+K_{\text {exch }} \frac{\max \left(0, \text { Exceedance }+A C_{\text {leach }, C L}\right)}{B C_{\text {leach }}}}
$$

Hence, when exceedance $=0, \Delta x=0$ and $B S_{f}=$ $B S_{C L}$; when exceedance $<0, \Delta x<0$ and $B S_{f}>B S_{C L}$; when exceedance $>0, \Delta x>0$ and $B S_{f}<B S_{C L}$, with $B S_{f}$ restricted to $0 \leq B S_{f} \leq 100$ for all cases. In principle, 
positive exceedances signal continued base-cation depletion towards lower $B S$ values.

The annual base-cation losses or gains from current to final $B S$ levels can be derived from Eqn 4 by solving for $\Delta x$ :

$$
\Delta x=-0.5 a\left(1-\sqrt{1-4 b / a^{2}}\right)
$$

where $\mathrm{a}=\left[K_{\text {exch }}\left(B S+A C_{\text {leach }}\right)-B C_{\text {leach }}-(C E C-\right.$ $B S)] /\left(K_{\text {exch }}-1\right)$ and $b=\left[B S\left(K_{\text {exch }} A C_{\text {leach }}+B C_{\text {leach }}\right)-\right.$ $\left.C E C B C_{\text {leach }}\right] /\left(K_{\text {exch }}-1\right)$. For soils with $A C_{\text {leach }}$ and $B C_{\text {leach }}<<B S$, it can be shown that ( $B S$ and $B S_{f}$ in \%):

$$
\Delta x \approx \frac{100\left(B S-B S_{f}\right)}{B S B S_{f}\left(K_{\text {exch }}-1+100 / B S\right)} B C_{\text {leach }}
$$

Hence, base-cation losses or gains are therefore directly relatable to the current-to-final base-saturation differences and net base-cation inputs and outputs (i.e., $\left.B C_{\text {leach }}\right)$. The $B S$ to $B S_{f}$ turn-over time for exchangeable base cations is therefore given by:

$$
\begin{gathered}
\left(B S-B S_{f}\right) / \Delta x \approx 10^{-4} B S B S_{f} \\
\left(K_{\text {exch }}-1+100 / B S\right) C E C / B C_{\text {leach }}
\end{gathered}
$$

This equation implies that $\left(B S-B S_{f}\right) / \Delta x$ increases with increasing $C E C$ and decreasing $B C_{\text {leach }}$, and also implies short turn-over times in shallow soils with decreasing base-saturation (sandy soils) and in soils with high acid- to base-cation affinities, i.e., large $K_{\text {exch }}$ values.

For acidic soil leachates, $\mathrm{H}^{+}$and $\mathrm{Al}^{3+}$ are the dominant acid cations such that:

$$
\left[A C_{\text {leach }}\right]=A C_{\text {leach }} / Q=\left[H^{+}\right]_{\text {leach }}+3\left[A l^{3+}\right]_{\text {leach }}
$$

where $Q$ is the soil percolation rate, and where the square brackets for $\mathrm{H}^{+}$and $\mathrm{Al}^{3+}$ denote their concentrations. These concentrations are assumed to follow the dissolution-precipitation equilibrium of gibbsite:

$$
K_{\text {gibbs }}=\left[A l^{3+}\right] /\left[H^{+}\right]^{3}
$$

In principle, $\left[H^{+}\right]_{\text {leach, } C L}$ and $\left[A l^{3+}\right]_{\text {leach,CL }}$ can therefore be determined from Eqns 6,10 and 11. In the current study, $K_{\text {exch }}$ was set at 10 and $\log _{10}\left(K_{\text {gibbs }}\right)$ was set at 8.5 to best reflect the overall acid / base and $\mathrm{H}^{+}$/ $\mathrm{Al}^{3+}$ conditions at the soil-subsoil interface.

The model formulation applies to upland areas only as lowlands receive base-cation enriched upland seepage and groundwater discharge. In addition, lowland soils subject to poor drainage transform incoming $\mathrm{S}$ to insoluble sulphides (at least in part), incoming nitrate- $\mathrm{N}$ to gaseous $\mathrm{N}$ losses, and export some to the accumulated $\mathrm{N}$ by way of dissolved organic matter. Hence, in comparison to uplands, one should expect exceedances for lowland soils to be low if not absent. As such, it is important to delineate uplands from lowlands systematically, and to determine the resulting exceedance pattern accordingly, with lowland exceedances categorically assumed to be $\leq 0$.
While the formulation presented here accounts for net $\mathrm{N}$ and $\mathrm{BC}$ uptake by forest vegetation, tracking such uptake across the Georgia Basin requires considerable efforts for short- and long-term considerations. For example, estimating local forest growth and related nutrient uptake depends on determining local forest conditions (stand age, species composition, stem density) as these vary dynamically with stand age, surface disturbances regimes due to forest fires and insect infestations and forest harvesting, including timing, practices and intensity (e.g., whole-tree, stem-only, biomass, salvage, etc.). In general, all or most of the atmospherically deposited $\mathrm{N}$ would at first be retained by the vegetation, but would then be subject to $\mathrm{N}$ mineralization (Zhang et al. 2008), and subsequent $\mathrm{N}$ losses due to, e.g., leaching, forest fires and forest harvesting. The following evaluation addresses long-term considerations only, and assumes zero $\mathrm{N}$ and $\mathrm{BC}$ net uptake, as would be the case for old-growth forests, and for forests that return to the same $\mathrm{N}$ and $\mathrm{BC}$ status after each harvest rotation or disturbance cycle. The opposite assumption, i.e., that all of the incoming $\mathrm{N}$ would be taken up and retained by the vegetation indefinitely, may represent a less severe soil acidification scenario. However, $\mathrm{N}$ uptake is at least partially compensated by soil-acidifying BC uptake. Further, owing to a general lack of geospatial and ecosystem-level information on $\mathrm{N}$ fixation and immobilization (McLauchlan et al. 2007), $\mathrm{N}_{\mathrm{imm}}$ and $\mathrm{N}_{\mathrm{fix}}$ were set to zero in the current study.

\subsection{Data compilation and processing}

Determining CL and exceedance values for any particular area requires a systematic compilation of data layers dealing with atmospheric conditions and inputs (air temperature, precipitation volume and chemistry), bedrock geology, biogeoclimatic ecosystem classification (BEC), hydrography, topography, and local soil survey reports (Arp et al. 2001). For the Georgia Basin, the following data layers were consulted for determining CL, exceedances and base-cation depletion:

(i) the digital elevation model (DEM) and hydrographic atlas (Government of British Columbia);

(ii) the digital geology map of British Columbia (1:250,000: Massey et al. 2003);

(iii) the BEC map for British Columbia (Fig. 1: Ministry of Forests, Research Branch, 1:250,000: Meidinger \& Pojar 1991);

(iv) the 1961-1990 monthly mean normals for temperature and precipitation (Parameter-elevation Regressions on Independent Slopes Model (PRISM: www.ocs.orst.edu/prism), $4 \mathrm{~km}^{2}$ grid: Daly et al. 2002);

(v) annual atmospheric $\mathrm{N}, \mathrm{S}, \mathrm{Ca}^{2+}, \mathrm{Mg}^{2+}$ and $\mathrm{K}^{+}$wet deposition, based on geospatial interpolation of observed precipitation-weighted concentrations obtained from the National Atmospheric Chemistry (NatChem) database (Fig. 2) converted to 


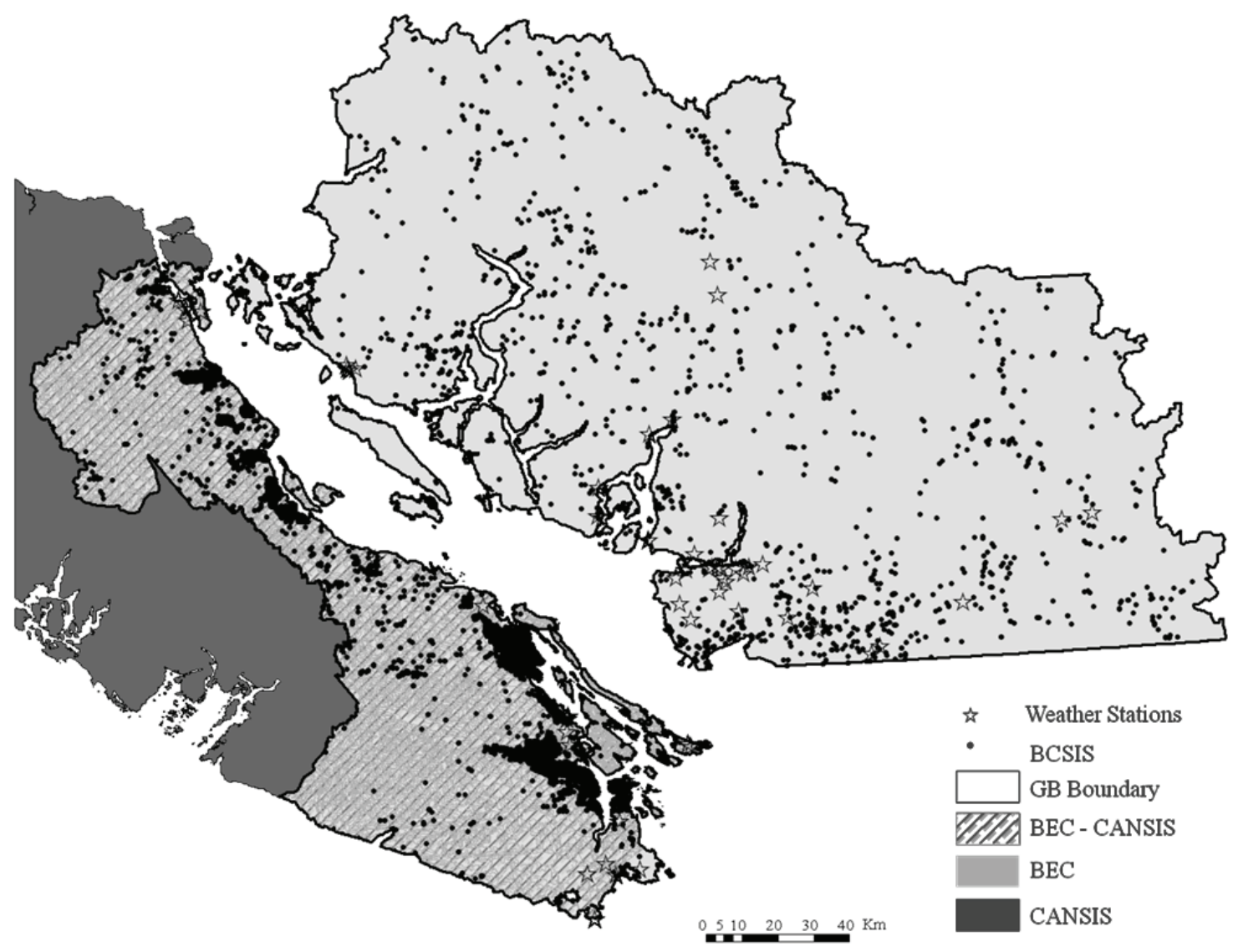

Fig. 1. Delineation of the Georgia Basin, British Columbia showing coverage for the Canadian soil information system (CANSIS: hatched) and biogeoclimatic ecosystem classification (BEC: light grey) map units. Soil sampling locations of the British Columbia soil information system (BCSIS) (dot) and meteorological (weather) stations (star) are also shown.

deposition using PRISM precipitation volume (Fig. 3);

(vi) modelled annual average total (wet and dry) deposition for $\mathrm{S}$ and $\mathrm{N}\left(4 \mathrm{~km}^{2}\right.$ grid) for the period 2005-2006 (Fig. 3: Community Multiscale Air Quality modelling (CMAQ) using MC2 meteorology; Boulton et al. 2003, 2009, Queen \& Zhang 2008).

A portion of the incoming acid- and base-cation loads by-pass the soil during high run-off periods, especially during snowmelt. The annual estimates for deposition were therefore reduced by the fraction of the year during which these loads would accumulate in the form of snow and ice, so that atmospheric deposition loads entering the soil $=$ annual deposition loads $\times(1-f)$, with $f$ estimated from the mean monthly temperatures in January and July, as follows:

$$
f=\max \left(-T_{\text {January }}, 0\right) /\left(T_{\text {July }}-T_{\text {January }}\right)
$$

The Georgia Basin does not have a complete soil survey coverage (Fig. 1). Hence, it was necessary to devise procedures to produce a consistent soil attribute layer for soil depth (rooted layers only), and soil layerweighted averages for texture (sand, silt, clay content), soil organic matter and coarse fragment content (\%), soil $\mathrm{pH}, \mathrm{CEC}$, exchangeable base cations $\left(\mathrm{Ca}^{2+}+\mathrm{Mg}^{2+}\right.$ $+\mathrm{K}^{+}$), soil parent material (mode of deposition), and bedrock lithology (Tab. 1). This information was generated by compiling and processing: (i) the individual soil map sheets from the Canadian soil information system (CANSIS), showing soil polygons and select soil attributes for the region, (ii) the British Columbia soil information system (BCSIS) soil sampling data, and (iii) BEC attributes pertaining to soil and site type (see Fig. 1). The following steps were used to complete this coverage. Step 1: Soil data contained in CANSIS and BCSIS reports were compiled by soil polygon location, and by soil layer within each soil polygon. Step 2: Missing or erroneous data entries were identified at the soil-layer level, and were substituted using various techniques involving systematic cross-referencing, regression analysis, discerning trends within soil type by layer, and averaging by layer of same type across soil profiles, depending on the nature and extent of the missing data (Tab. 1). Step 3: Missing data for $\rho_{b}$ were estimated following Balland et al. (2008). Missing data for $\mathrm{OM}$ were in part obtained by multiplying data for organic soil carbon by 1.72 , or multiplying data for soil $\mathrm{N}$ with an estimated carbon-to-nitrogen ratio per soil layer type. 

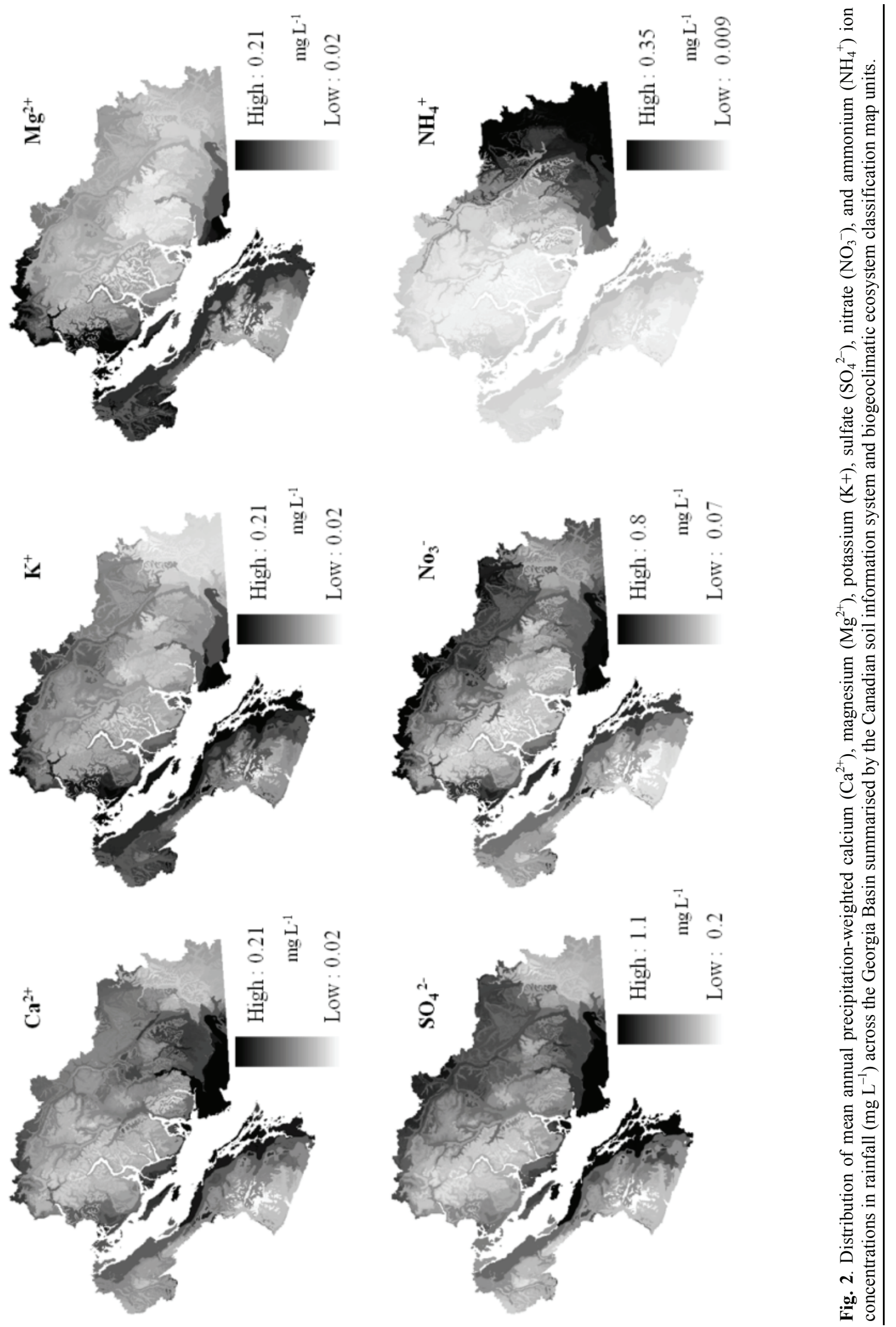

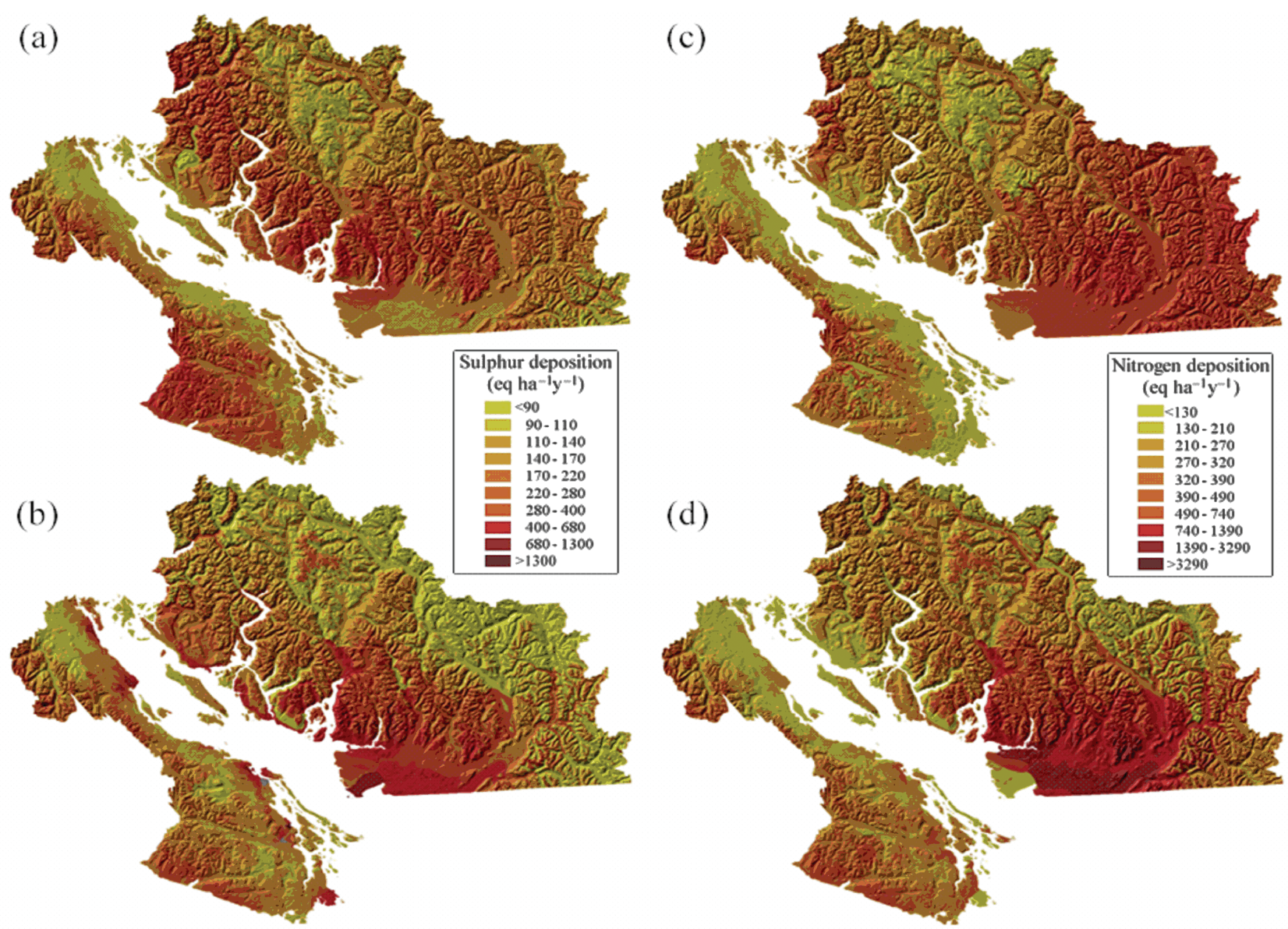

Fig. 3. Distribution of (a) wet sulphur, (b) total (wet and dry) sulphur, (c) wet nitrogen, and (d) total nitrogen deposition (eq ha $\left.{ }^{-1} \mathrm{y}^{-1}\right)$ across the Georgia Basin. Wet deposition was interpolated from all available precipitation chemistry observations (NatChem); modelled total deposition for the period 2005-2006 was obtained from the CMAQ model.

Tab. 1. Soil attributes and the extent of generated data for the Georgia Basin by information source [British Columbia soil information system (BCSIS) and Canadian soil information system (CANSIS)].

\begin{tabular}{|c|c|c|c|c|}
\hline \multirow{2}{*}{ Soil attributes } & \multicolumn{2}{|c|}{ BCSIS } & \multicolumn{2}{|c|}{ CANSIS } \\
\hline & No. of records & $\begin{array}{c}\text { Generated values } \\
\text { (\%) }\end{array}$ & No. of records & $\begin{array}{c}\text { Generated values } \\
(\%)\end{array}$ \\
\hline Soil layers & 120,650 & 1 & 3953 & 0 \\
\hline Depth & 117,942 & 3 & 3932 & 1 \\
\hline Coarse fragment & 76,676 & 37 & 1069 & 73 \\
\hline Soil texture & 86,110 & 29 & 3953 & 0 \\
\hline $\mathrm{pH}\left(\mathrm{CaCl}_{2}\right)$ & 25,099 & 79 & 1384 & 65 \\
\hline $\mathrm{pH}\left(\mathrm{H}_{2} \mathrm{O}\right)$ & 24,683 & 80 & 1204 & 70 \\
\hline Carbon (organic) & 24,621 & 80 & 1445 & 63 \\
\hline Nitrogen (total) & 24,621 & 80 & 1502 & 62 \\
\hline $\mathrm{CEC}$ & 24,621 & 100 & 2192 & 45 \\
\hline Exchangeable $\mathrm{Ca}^{2+}$ & 24,621 & 80 & 1677 & 58 \\
\hline Exchangeable $\mathrm{Mg}^{2+}$ & 24,621 & 80 & 2060 & 48 \\
\hline 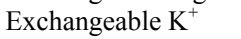 & 24,621 & 80 & 2361 & 40 \\
\hline Exchangeable $\mathrm{Na}^{+}$ & 24,621 & 80 & 2305 & 42 \\
\hline Base saturation & 24,621 & 100 & 1184 & 70 \\
\hline Sand & 24,621 & 80 & 1069 & 73 \\
\hline Silt & 24,621 & 80 & 1335 & 66 \\
\hline Clay & 24,621 & 80 & 2597 & 34 \\
\hline Bulk density & 0 & 100 & 0 & 100 \\
\hline
\end{tabular}


Missing data for CEC were in part generated following Meyer et al. (1994), using specified values for clay and $\mathrm{OM}$ content, and soil $\mathrm{pH}\left(\mathrm{H}_{2} \mathrm{O}\right)$. Step 4: The soil-layer attributes required for $\mathrm{CL}$ mapping were weight-averaged for each soil profile (rooted soil depth only), by soil polygon (CANSIS) or by soil sampling location (BCSIS). Step 5: The CANSIS map units without soil attribute data were populated with the weight-averaged soil attributes for all the BCSIS soil survey points. Step 6: Map units without CANSIS coverage were processed similarly, but with weight-averaged BCSIS soil attributes assigned to each local BEC map unit. Step 7: For BEC units with no BCSIS points, it was decided to average the soil attributes of all BCSIS points falling into a particular BEC class.

Critical load and exceedance estimates were generated for each map unit. This was carried out by averaging the deposition values per map unit (Figs $2 \& 3$ ), and joining the resulting values to the finalized soil attribute table. The DEM was utilised to delineate lowland areas within and across each map unit following Murphy et al. $(2009 \mathrm{a}, \mathrm{b})$. The lowland areas so defined were assumed to be subject to base-cation enrichment rather than depletion, with lowland exceedances subsequently and categorically assigned to be $\leq 0$. In general, the CANSIS map units allowed for finer and more varied $\mathrm{CL}$ and exceedance determinations than the BEC map units. However, the CANSIS coverage was restricted to Vancouver Island and islands within the Strait of Georgia (Fig. 1). Moreover, the BCSIS point locations (used to populate the soil attributes for each BEC unit) varied from widely spaced to highly clustered (Fig. 1). As such, the empirical foundation of the soil attribute file and resultant $\mathrm{CL}$ and exceedance calculations varied across the region.

\section{RESULTS AND DISCUSSION}

The geospatially interpolated ion concentrations for $\mathrm{NO}_{3}^{-}, \mathrm{NH}_{4}^{+}, \mathrm{SO}_{4}{ }^{2-}, \mathrm{Ca}^{2+}, \mathrm{Mg}^{2+}$ and $\mathrm{K}^{+}$in precipitation (derived from NatChem) generally decreased with increasing elevation (Fig. 2). This dilution is empirically related to increasing precipitation with increasing elevation (details not shown). Most notable are the elevated ion concentrations within the southern portion of the mainland (Vancouver and Lower Fraser Valley), where local atmospheric emissions would add to the atmospheric ion loads. Increased concentrations also occur along the east coast of Vancouver Island, and further north and east on the mainland, mainly due to lower precipitation rates. The base cation, $\mathrm{NO}_{3}{ }^{-}$and $\mathrm{SO}_{4}{ }^{2-}$ concentration patterns are quite similar to one another, but the $\mathrm{NH}_{4}^{+}$concentration pattern increases distinctly to the southeast, likely corresponding to agriculturally based $\mathrm{NH}_{4}{ }^{+}$emissions. The wet (NatChem) and modelled total (CMAQ) atmospheric deposition pattern for $\mathrm{S}$ and $\mathrm{N}$ are, on the whole, quite similar (Fig. 3); however, modelled total deposition revealed a number of hotspots, with high loads along the eastern part of Vancouver Island and the northern uplands of the Lower Fraser Valley.

Critical loads of acidity for soils based on a zero base-cation depletion criterion and subsequent exceedances under wet and total $\mathrm{S}$ and $\mathrm{N}$ deposition were mapped for the Georgia Basin (Fig. 4). Generally, $\mathrm{CL}$ values were lowest, and exceedances were highest at high elevations and along steep valley slopes. This is not unexpected due to shallow soils on rock-exposed ridge tops, steep slopes and lower weathering rates. Towards valleys and gentler slopes, estimated CL values tended to increase, while exceedance values tended to decrease (Fig. 4). Here, the soils (as mapped) are deeper, less stony and warmer, thereby increasing the local soil weathering estimates.

Translating the estimated $\mathrm{CL}$ exceedances under total $\mathrm{S}$ and $\mathrm{N}$ deposition into base-cation depletion (via Eqn 8) indicated that this depletion would be of little consequence in areas with low soil base saturation, such as the high elevation areas on Vancouver Island (Fig. 5). This, however, would not be the case for soils of medium to high base saturation where net acid-cation inputs were estimated to exceed net base-cation inputs, especially along the northern section of the lower Fraser Valley, and also along the southern part of Vancouver Island (Fig. 5). Here, the estimated base-cation depletion rates would be relatively fast, especially in shallow soils with high sand content.

The $B S_{C L}$ values (Fig. 5), identical to the $B S$ values compiled from the CANSIS and BCSIS soil surveys as outlined above, range from less than $10 \%$ to more than $100 \%$, depending on the nature of local substrates and climate conditions. Generally, these values decrease in areas with high precipitation, e.g., on Vancouver Island and along the western portion of the mainland. In contrast, $B S$ values are high in rain-shadow areas along the eastern part of Vancouver Island, and the eastern part of the mainland portion of the Georgia Basin. The estimated $A C_{\text {leach, } C L}$ pattern (not shown) is similar to the $B S$ pattern, generally high where $B S$ values are low, and vice versa, and with $A C_{\text {leach, } C L}=0$ when $B S \geq 100 \%$, as stipulated above.

The CL exceedances ranged from 13\% under wet deposition (NatChem) to $32 \%$ under modelled wet and dry deposition (CMAQ) across the Georgia Basin. These numbers increase by an additional $10 \%$ when considering upland areas only, i.e., approximately $42 \%$ of the upland areas within the Georgia Basin are potentially subject to enhanced soil acidification owing to $\mathrm{S}$ and $\mathrm{N}$ inputs. Most of the exceeded areas would be subject to small positive exceedances only; however, a small portion of the area would experience exceedances in excess of 1000 eq ha ${ }^{-1} \mathrm{y}^{-1}$ on account of combined (wet and dry) $\mathrm{S}$ and $\mathrm{N}$ deposition (Fig. 6). 


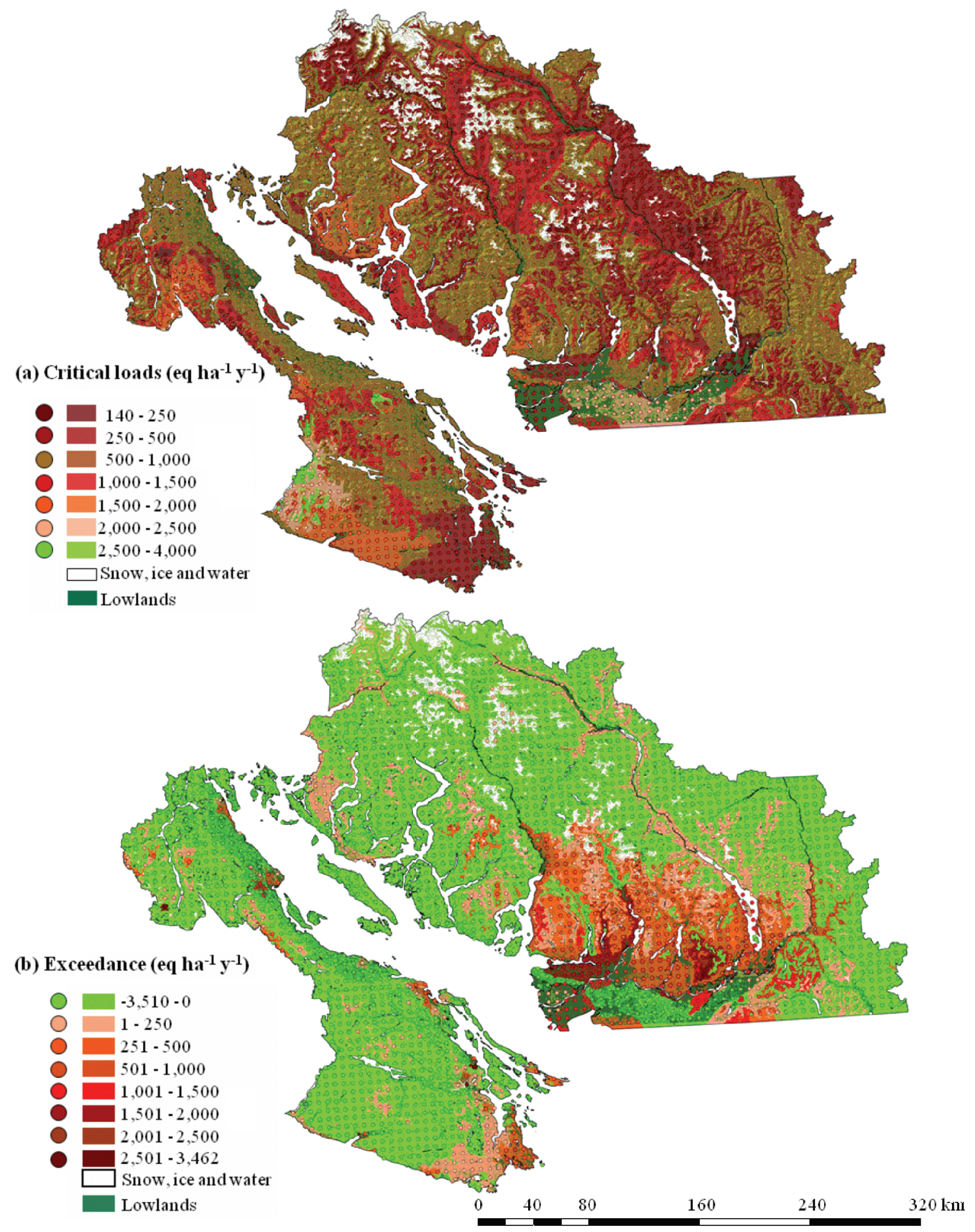

Fig. 4. Distribution of (a) critical loads of acidity (sulphur and nitrogen) for soil and (b) exceedance (eq ha $\mathrm{y}^{-1}$ ) under modelled total deposition (CMAQ 2005-2006) across the Georgia Basin summarised by the Canadian soil information system and biogeoclimatic ecosystem classification map units. Estimates are also shown for each CMAQ grid point. 

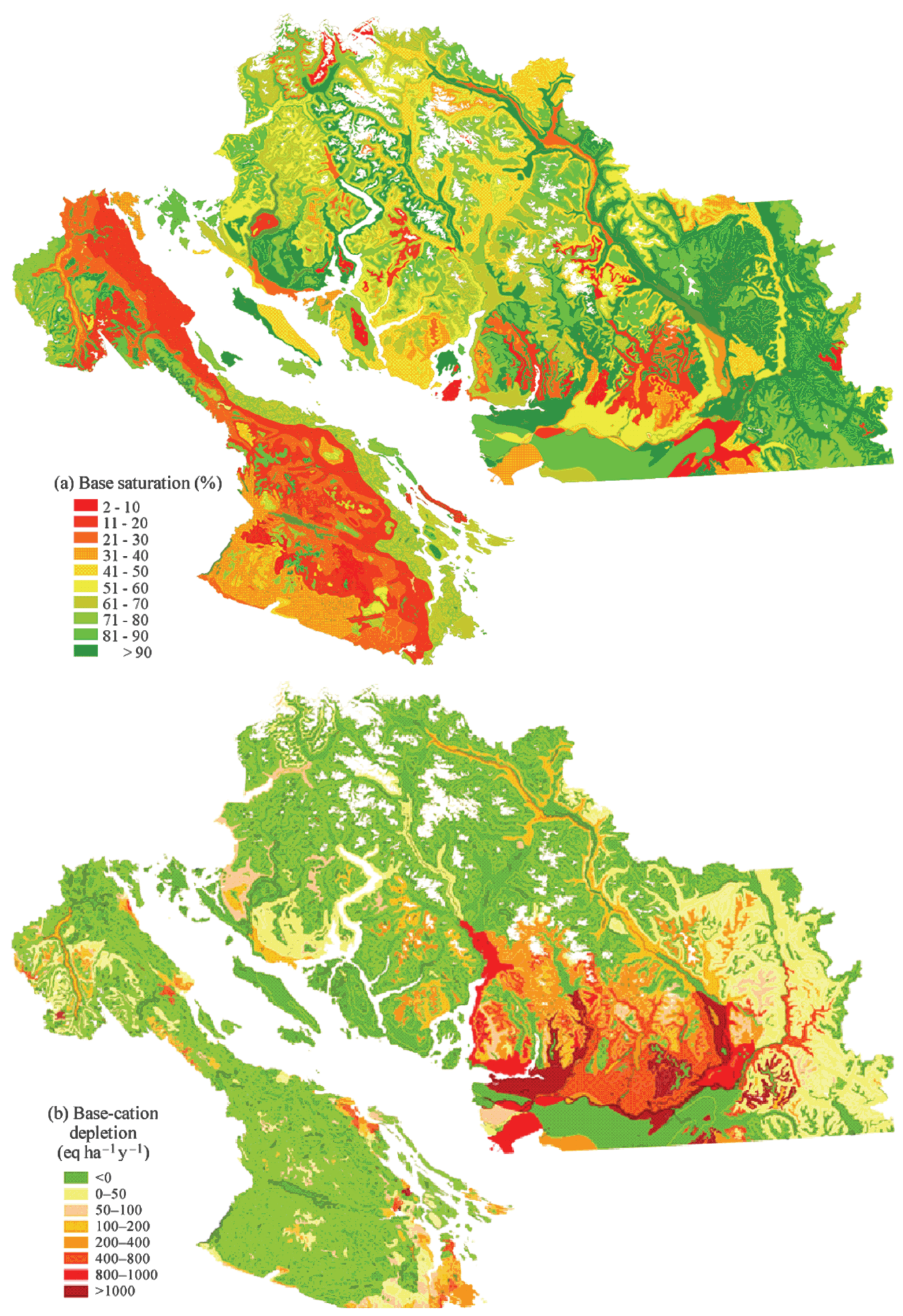

Fig. 5. Distribution of (a) base saturation (\%) identified as the critical base saturation values to maintain no further base-cation losses and (b) base-cation depletion under modelled total (wet and dry) sulphur and nitrogen deposition (CMAQ). Data are summarised by the Canadian soil information system and biogeoclimatic ecosystem classification map units, for areas not covered by ice. 


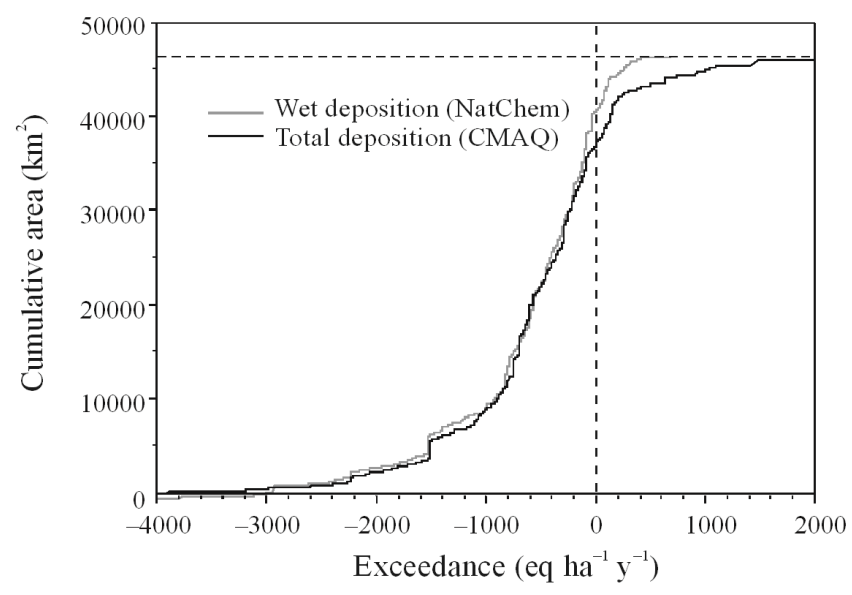

Fig. 6. Cumulative critical load exceedance (eq ha ${ }^{-1} \mathrm{y}^{-1}$ ) under modelled total (wet and dry) sulphur and nitrogen deposition (CMAQ) and wet sulphur and nitrogen deposition (NatChem), for areas not covered by ice.

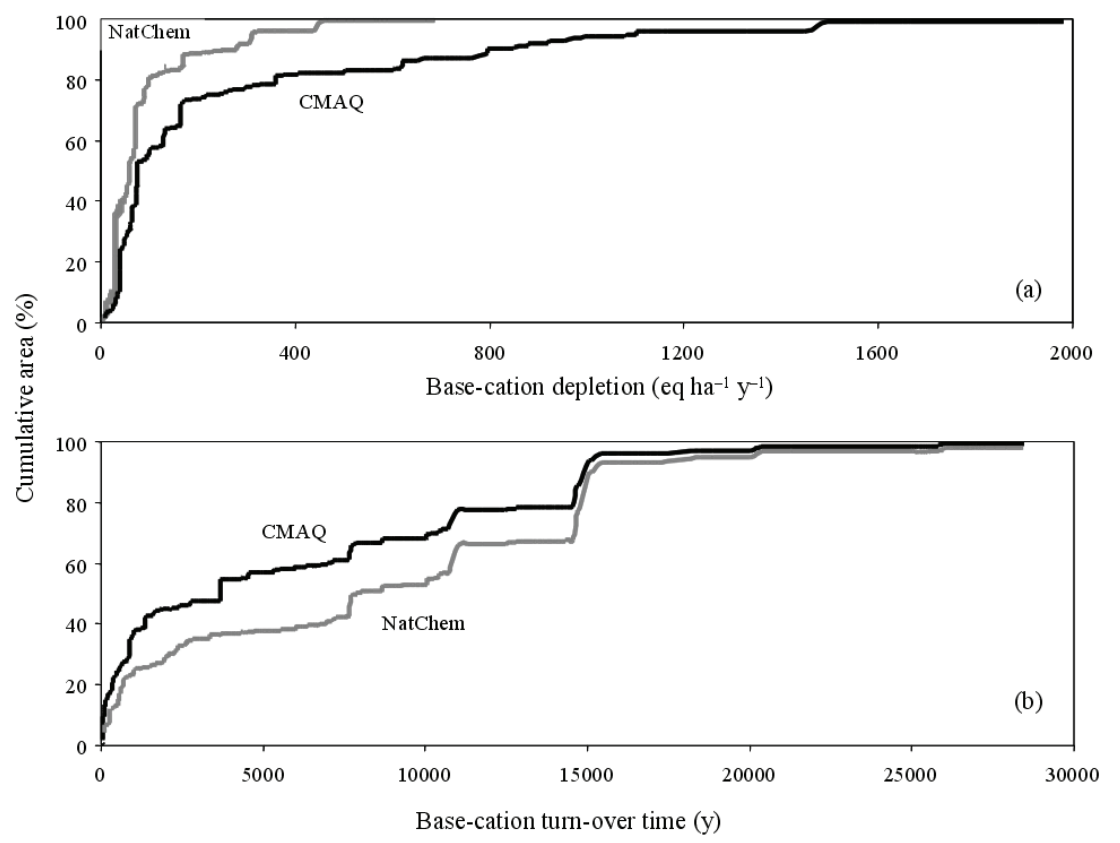

Fig. 7. Cumulative (a) base-cation depletion (eq ha $\mathrm{y}^{-1}$ ) and (b) base-cation turnover times (y) from current to estimated final basesaturation under modelled total (wet and dry) sulphur and nitrogen deposition (CMAQ) and wet sulphur and nitrogen deposition (NatChem) for exceeded areas only.

Altogether, significant portions of the Georgia Basin are predicted to experience exceedance-enhanced basecation depletion rates above $200 \mathrm{eq} \mathrm{ha}^{-1} \mathrm{y}^{-1}$ and turnover times to a final new base cation state $\left(B S_{f}\right)$ within 200 years under continued atmospheric $\mathrm{S}$ and $\mathrm{N}$ deposition (as summarized in Fig. 7). Here, the estimated base cation depletion rates vary from $<0$ to about 2000 eq ha $^{-1} \mathrm{y}^{-1}$, while the estimated base-cation turnover times (from current to final values) range over several orders of magnitude, from about 20 to 50,000 years (average about 3700 years). Generally, these turn-over times increase with the amount of exchangeable bases currently stored in the soil, and decrease with local exceedance estimates. This attests to the site-specific nature of base-cation depletion, and to the difficulties associated with discerning trends from short-term field observations and studies (Kreutzweiser et al. 2008). Critical load, exceedance and base-cation depletion maps (Figs 4 \& 6) may serve as a platform for selecting areas requiring detailed soil and forest health observations, with special focus on (i) base-cation content on exchange sites, in soil leachates, and in roots and foliage, (ii) canopy transparencies as well as leaf and needle size, and (iii) tree-growth performance, especially in response to base-cation amendments (Fenn et al. 2006).

The above approach can be compared with the traditionally set CL criteria for upland soil acidification such as (i) the maximum acceptable $\mathrm{Al}$ to $\mathrm{BC}$ ratio 
$\left[(A l / B C)_{c r i t}\right]$, (ii) the maximum acceptable $\mathrm{Al}$ concentration, and (iii) the minimum acceptable $\mathrm{pH}$ of the soil leachates. Although widely used, studies have shown that these criteria and the resulting exceedance estimates require further investigation to establish direct linkages between ecosystem responses and exceedances (Hall 2001). Within the context of the current study, these criteria may serve as additional means to set limits to the export of acid and base cations from soils. For example, average CL values were estimated to increase from $\approx 1440$ (using the $\Delta x=0$ criterion) to $\approx 2090 \mathrm{eq} \mathrm{ha}^{-1}$ $\mathrm{y}^{-1}$ (using the $(A l / B C)_{\text {crit }} \leq 0.1$ criterion); however, below $B S \leq \approx 10 \%$, the $(A l / B C)_{\text {crit }} \leq 0.1$ criterion resulted in lower critical loads. Across the Georgia Basin, this condition would apply to $3.4 \%$ of the area; elsewhere, $B S_{C L}$ would be the more sensitive criterion.

The approach presented here can undoubtedly be improved (i) by considering more detailed acid-base cation-exchange formulations, empirically and theoretically (Matschonat \& Vogt 1998; Skyllberg et al. 2001; Johnson 2002), and (ii) by revising the soil weathering calculations. Generally, Eqn 3 produced soil weathering rates similar in range and magnitude compared to those obtained through more detailed means (see, e.g., Hodson \& Langan 1999; Akselsson et al. 2004; Ouimet \& Duchesne 2005; Watmough \& Dillon 2006; Mongeon et al. 2010, this issue). Nevertheless, and ideally, soil weathering estimates should be derived from actual soil mineral contents and knowledge of reactive soil surfaces, by soil layer (Warfvinge \& Sverdrup 1992; Whitfield et al. 2006; Whitfield et al. 2010, this issue), (iii) refining the atmospheric deposition loads for dry and wet deposition (Boulton et al. 2009) within the context of contemplated and actual air pollution abatement policies and targets, (iv) adding a detailed forest inventory component to address $\mathrm{BC}$ and $\mathrm{N}$ related harvest exports (Moayeri et al. 2001), (v) examining results of standand watershed-based nutrient input/output investigations, especially within the study region (Feller et al. 2000; Feller 2005; Feller 2010, this issue), and (vi) dealing with $\mathrm{BC}$ and $\mathrm{N}$ uptake in a locally systematic fashion, based on, e.g., detailed forest management plans. Systematic investigations pertaining to vegetation-, landform- and topography-induced variations in soil mineralogy, depth, texture, organic matter, $\mathrm{pH}$, CEC, BS, and soil drainage would also be helpful. The upland / lowland delineation would assist in this regard as a means to discern differentiation of soil responses to atmospheric deposition, at high resolution, over time.

\section{CONCLUSIONS}

In principle, determining $\mathrm{CL}$, exceedance and basecation depletion for the Georgia Basin (and elsewhere) remains a challenge, on account of the relatively sparse information on local variations in soils and geological substrates, the highly variable surface and land-use conditions including forest operations, the differing tech- niques and resolutions in assessing atmospheric deposition, and the technical and conceptual uncertainties pertaining to estimating soil weathering and leaching rates. Higher resolution data would help to sharpen the focus on upland areas that may potentially be affected by enhanced atmospheric $\mathrm{S}$ and $\mathrm{N}$ deposition. For the Georgia Basin, up to $32 \%$ of the area may be subject to acid-deposition induced base-cation depletion, with the highest exceedances occurring in the northern uplands of the Lower Fraser Valley. While exceedances can be as high as about 3500 eq ha ${ }^{-1} \mathrm{y}^{-1}$ in certain locations, they are generally $<500 \mathrm{eq} \mathrm{ha}^{-1} \mathrm{y}^{-1}$. Regions estimated to incur high exceedances, and therefore high basecation depletion rates, should be surveyed regarding notable soil and forest health impacts.

\section{ACKNOWLEDGMENTS}

This research was supported by Environment Canada's Georgia Basin Action Plan, with additional support received by PAA from the Natural Science and Engineering Council of Canada (Discovery Grants). We are grateful to: Pat Shaw and Silvina Carou (Environment Canada) for guidance and managerial support, to Roxanne Vingarzan and Colin diCenzo for access to the CMAQ $\mathrm{S}$ and $\mathrm{N}$ deposition grid, the reviewers of this paper, and to Pat Shaw and Julian Aherne for their editorial work. We are also grateful to W.L. Meyer for producing laboratory-type soil acidification and basecation leaching data and Kexch evaluations pertaining to Eqn 4 for soil profiles in New Brunswick, Quebec, and Ontario.

\section{REFERENCES}

Akselsson, C., J. Holmquist, M. Alteveg, D. Kurz \& H. Sverdrup. 2004. Scaling and mapping regional calculations of soil chemical weathering in Sweden. Water Air Soil Pollut. Focus, 4: 671-681.

Arp, P.A., W. Leger, M. Moayeri \& J.E. Hurley. 2001. Methods for mapping forest sensitivity to acid deposition for northeastern North America. Ecosyst. Health, 7: 35- 47.

Balland, V., J.A.P. Pollacco \& P.A. Arp. 2008. Modelling soil hydraulic properties for a wide range of soil conditions. Ecol. Modell., 219: 300-316.

Boulton, J.W., M. Gauthier, X. Qiu \& M. Lepage. 2009. Emission inventory preparation and air quality modelling in the Pacific Northwest. (online: www.epa.gov/ ttn/chief/ conference/ei12/modeling/gauthier.pdf)

Boulton, J.W., M. Lepage, X. Qiu, M.Gauthier \& C. di Cenzo. 2003. New developments and applications of models-3 in Canada. 2003 Models-3 User's Workshop, Research Triangle Park, NC.

Daly, C., W.P. Gibson, G.H. Taylor, G.L. Johnson \& P. Pasteris. 2002. A knowledge-based approach to the statistical mapping of climate. Clim. Res., 22: 99-113.

de Vries, W. 1991. Methodologies for the assessment and mapping of critical loads and of the impact of abatement strategies on forest soils. Report 46, DLO The Winand Staring Centre, Wageningen, The Netherlands: 109 pp.

Dise, N.B., E. Matzner, M. Armbruster \& J. MacDonald. 2001. Aluminum output fluxes from forest ecosystems in Europe: a regional assessment. J. Environ. Qual., 30: 1747-1756. 
Duchesne, L. \& D. Houle. 2006. Base cation cycling in a pristine watershed of the Canadian boreal forest. Biogeochem., 78: 195-216.

Environment Canada. 2004. Canadian acid deposition science assessment. Ottawa: Environment Canada Meteorological Service of Canada: $440 \mathrm{pp}$.

Feller, M.C., R. Lehmann \& P. Olanski. 2000. Influence of forest harvesting intensity on nutrient leaching in southwestern British Columbia. J. Sust. For., 10: 241-247.

Feller, M.C. 2005. Forest harvesting and streamwater inorganic chemistry in western North America: a review. $J$. Amer. Wat. Res. Assoc., 41: 785-811.

Feller, M.C. 2010. Trends in precipitation and streamwater chemistry in East Creek watershed in southwestern British Columbia, 1971-2008. J. Limnol., 69(Suppl. 1): 77-91. DOI: $10.3274 /$ JL10-69-S1-09.

Fenn, M.E., T.G. Huntington, S.B. McLaughlin, C. Eagaram, A. Gomez \& R.B. Cook. 2006. Status of soil acidification in North America. J. For. Sci., 52: 3-13.

Hall, J., B. Reynolds, S. Langan, M. Hornung \& J. Aherne. 2001. Investigating the uncertainties in the Simple Mass Balance equation for acidity critical loads for terrestrial ecosystems in the United Kingdom. Water Air Soil Pollut. Focus, 1: 43-56.

Hodson, M.E. \& S.J. Langan. 1999. The influence of soil age on calculated mineral weathering rates. Appl. Geochem., 14: 387-394.

Houle, D., R. Ouimet, S. Couture \& C. Gagnon. 2006. Base cation reservoirs in soil control the buffering capacity of lakes in forested catchments. Can. J. Fish. Aquat. Sci., 63: 471-474.

Huntington, T.G. 2005. Assessment of calcium status in Maine forests: review and future projection. Can. J. For. Res., 35: 1109-1121.

Johnson, C.E. 2002. Cation exchange properties of acid forest soils of the northeastern USA. Eur. J. Soil Sci., 53: 271282.

Kreutzweiser, D.P., P.W. Hazlett \& J.M Gunn. 2008. Logging impacts on the biochemistry of boreal soils and nutrient exports to aquatic systems: a review. Environ. Rev., 16: $157-179$.

McLauchlan, K.K., J.M. Craine, W.O. Wyatt, P.R. Leavitt \& G.E. Likens. 2007. Changes in nitrogen cycling during the past century in a northern hardwood forest. Proc. Nat. Acad. Sci., 104: 7466-7470.

Massey, N.W.D., D.G. MacIntyre \& P.J. Desjardins. 2003: Digital Map of British Columbia: Tile NM10 southwest B.C., B.C. Ministry of Energy and Mines, Geofile 2003-3 (version 2), scale 1:250,000.

Matschonat, G. \& R. Vogt. 1998. Significance of the total cation concentration in acid forest soils for the solution composition and the saturation of exchange sites. Geoderma, 84: 289-307.

Meidinger, D. \& J. Pojar (compilers and editors). 1991. Ecosystems of British Columbia. B.C. British Columbia Forest Service, Research Branch. Special Report Series 06: 330 pp.

Meyer, W.L., M. Marsh \& P.A. Arp. 1994. Cation exchange capacities of upland soils in Eastern Canada. Can. J. Soil Sci., 1994: 393-408.

Moayeri, M., B. Simpson, F.-R. Meng, P.A. Arp \& N. Foster. 2001. Evaluating critical soil acidification loads and exceedances for a tolerant hardwood site at Turkey Lakes, Ontario. Ecosystems, 4: 555-567.

Mongeon, A., J. Aherne \& S.A. Watmough. 2010. Steadystate critical loads of acidity for forest soils in the Georgia Basin, British Columbia. J. Limnol., 69(Suppl. 1): 193200. DOI: 10.3274/JL10-69-S1-19.
Murphy, P.N.C., J. Ogilvie \& P.A. Arp. 2009a. Topographic modelling of soil moisture conditions: a comparison and verification of two models. Eur. J. Soil Sci., 60: 94-109.

Murphy, P.N.C., M. Castonguay, J. Ogilvie, M. Nasr, P. Hazlett, J. Bhatti \& P.A. Arp. 2009b. A geospatial and temporal framework for modeling gaseous $\mathrm{N}$ and other $\mathrm{N}$ losses from forest soils and basins, with application to the Turkey Lakes Watershed Project, in Ontario, Canada. For. Ecol. Manage., 258: 2304-2317.

Nilsson, J. \& P. Grennfelt (Eds). 1988. Critical loads for sulphur and nitrogen. Miliørapport 1988:15. NORD 1998:097 Nordic Council of Ministers, Copenhagen, Denmark: 418 pp.

Posch, M., J. Slootweg \& J.-P. Hettelingh (Eds). 2005. European critical loads and dynamic modelling. Coordination Center for Effects National Environmental Assessment Agency, Bilthoven, Netherlands, RIVM Report No. 259101016, ISBN No. 90-6960-128-1.

Ouimet, R., L. Duchesne, D. Houle \& P.A. Arp. 2001. Critical loads and exceedances of acid deposition and associated forest growth in the northern hardwood and boreal coniferous forests in Québec, Canada. Water Air Soil Pollut. Focus, 1: 119-134.

Ouimet, R. \& L. Duchesne. 2005. Base cation mineral weathering and total release rates from soils in three calibrated forest watersheds on the Canadian Boreal Shield. Can. J. Soil Sci., 85: 245-260.

Ouimet, R., P.A. Arp, S.A. Watmough, J. Aherne \& I. DeMerchant. 2006. Determination and mapping of critical loads of acidity and exceedances for upland forest soils in Eastern Canada. Water Air Soil Pollut., 172: 57-66.

Queen, A. \& Y. Zhang. 2008. Examining the sensitivity of MM5-CMAQ predictions to explicit microphysics schemes and horizontal grid resolutions, Part III - The impact of horizontal grid resolution. Atmos. Environ., 42: 3869-3881.

Skyllberg, U., K. Raulund-Rasmussen \& O.K. Borggard. 2001. $\mathrm{pH}$ buffering in acidic soils developed under Picea abies and Quercus robur: Effects of soil organic matter, adsorbed cations and soil solution ionic strength. Biogeochem., 56: 51-74.

Warfvinge, P. \& H. Sverdrup. 1992. Calculating critical loads of acid deposition with PROFILE, A steady-state soil chemistry model. Water Air Soil Pollut., 63: 119-137.

Watmough, S. A. \& P.J. Dillon. 2001. Base cation losses from a coniferous catchment in Central Ontario, Canada. Water Air Soil Pollut. Focus, 1: 507-524.

Watmough, S.A. \& P.J. Dillon. 2006. Base cation and nitrogen budgets for a mixed hardwood catchment in South-Central Ontario. Ecosystems, 6: 675-693.

Whitfield, C.J., S.A. Watmough, J. Aherne \& P.J. Dillon. 2006. A comparison of weathering rates for acid-sensitive catchments in Nova Scotia, Canada and their impact on critical load calculations. Geoderma, 136: 899-911.

Whitfield, C.J., J. Aherne, S.A. Watmough \& M. McDonald. 2010. Estimating the sensitivity of forest soils to acid deposition in the Athabasca Oil Sands Region, Alberta. $J$. Limnol., 69(Suppl. 1): 201-208. DOI: 10.3274/JL10-69S1-20.

Wiens, J.H. 1987. Sensitivity of western and northern Canada soils and geology to acidic input. Victoria, B.C.: Technical Committee for the Long-Range Transport of Atmospheric Pollutants in Western and Northern Canada., Coordinating Committee on Soil and Geology Sensitivity Mapping (Canada).

Zhang, C.F., F.R. Meng, J.S. Bhatti, J.A. Trofymow \& P.A. Arp. 2008. Modelling forest leaf-litter decomposition and $\mathrm{N}$ mineralization in litterbags, placed across Canada: A 5model comparison. Ecol. Modell., 219: 342-360. 